\title{
Ailenin Karşıladı̆̆ Temel Psikolojik İhtiyaçlar Basic Psychological Needs Satisfied by Family
}

\author{
Mustafa KOÇ ${ }^{\star}$ \\ Doç. Dr., Sakarya Üniversitesi \\ Psikolojik Danışmanlık ve Rehberlik A.B.D. \\ Murat ISSENDER ${ }^{1}$ \\ T. Seda COLAK ${ }^{2}$ \\ Betül DÜSÜNCELİं \\ Zehra KOÇ4
}

\footnotetext{
* mkoc@sakarya.edu.tr

1 Doç. Dr., Sakarya Üniversitesi Psikolojik Danışmanlık ve Rehberlik Anabilim Dalı, iskender@sakarya.edu.tr

2 Yrd. Doç. Dr., Düzce Üniversitesi Psikolojik Danışmanlık ve Rehberlik Anabilim Dalı, tugbacolak@duzce.edu.tr

3 Arş. Gör. Dr., Sakarya Üniversitesi Psikolojik Danışmanlık ve Rehberlik Anabilim Dalı, bbayraktar@sakarya.edu.tr

4 Memur, Hendek Kaymakamlığı, zehrakoc_61@hotmail.com
} 


\section{Özet}

$1 \begin{aligned} & \text { raştırmanın temel amacı, hayatta kalma, ait olma ve sevgi, güç, özgürlük } \\ & \text { ve eğlence olarak belirlenen temel psikolojik ihtiyaçlar açısından ailenin } \\ & \text { profilini çıkarmaktır. Bir başka deyişle ailenin, bu temel psikolojik ihti- }\end{aligned}$ yaçlardan en çok hangisini karşıladığı ve en az ya da hiç karşılamadığı ihtiyacın hangisi olduğunu belirlemektir. Araştırmanın diğer amacı ise, ailenin temel psikolojik ihtiyaçları karşılama düzeyinin demografik özellikler açısından farklılaşıp farklılaşmadığını belirlemektir. Araştırma 400 anne ve 400 baba olmak üzere toplam 800 ebeveyn ile gerçekleştirilmiştir. Araştırmada veriler "Yapılandırılmış Görüşme Formu" ile toplanmıştır. Form iki bölümden oluşmaktadır. Birinci bölümde, katılımcılara ait demografik bilgilerin elde edildiği ifadeler bulunmaktadır. İkinci bölümde ise, ailenin karşıladığı temel psikolojik ihtiyacın hangisi olduğunu belirlemeye yönelik maddeler bulunmaktadır. Veriler frekans ve yüzdelikler şeklinde verilmiş, aynı zamanda grafikle de gösterilmiştir. Yapılan analizler sonucunda; ilk sırada yer alan ailenin karşıladığı temel psikolojik ihtiyaçlar sırasıyla; hayatta kalmak, ait olma ve sevgi, güç, özgürlük ve eğlence şeklinde sıralanmıştır. Cinsiyet değiş̧kenine göre karşılaştırıldığında erkek ebeveynler kadın ebeveynlerden daha yüksek düzeyde ailenin hayatta kalma temel psikolojik ihtiyacını karşıladığını belirtirken, kadın ebeveynler erkeklerden daha yüksek oranda ait olma ve sevgi temel psikolojik ihtiyacının aile tarafından karşılandığını belirtmişlerdir.

Anahtar Kelimeler: Glasser, Gerçeklik Terapisi, Temel Psikolojik İhtiyaçlar, Aile. 


\section{Abstract}

$\mathrm{T}$ he main aim of the research is to construct a profile of family from the point of basic psychological needs, which determined as survival, love and belonging, power or recognition, freedom, fun. In other words, the aim is to determine which needs family meets mostly or at least. The other aim of the research is if the level of needs is met by family is changed in terms of demographic features. The research performed by 400 mothers and 400 fathers, totally 800 parents. "Structured Interview Form" used to obtain data. The form consists two parts. First part includes statements about demographics of participants. Second part includes items, which is asked to determine which basic psychological need family meets. Data was shown in the form of frequencies and percentages. At the same time, graphics were used to show data. As results of analysis, basic psychological needs, which are met by family at the first rank, are listed as survival, love and belonging, power or recognition, freedom, fun respectively. When results are compared according to gender variable, fathers indicate survival basic psychological needs more than mothers, mothers indicate love and belonging basic psychological needs more than fathers as fulfilled by family.

Keywords: Glasser, Reality Therapy, Basic Psychological Needs, Family. 


\section{Giriş}

$\mathrm{T}$

üm canlılar gibi her insanın da kendine özgü ihtiyaçları vardır. Canlı organizmada bir ihtiyaç hissedildiğinde ve bunun sonrasında doyurulduğunda canlının biyolojik ve ruhsal dengesi sağlanmış olur. İhtiyaçların karşılanması huzur, rahatlama, haz ve doyum meydana getirir. İnsanların duyduğu ihtiyaçlar biyolojik, sosyal ve psikolojik olabilir. İnsanın yaşamını sağlıklı şekilde devam ettirebilmesi için; biyolojik ihtiyaçları kadar psikolojik ve sosyal ihtiyaçlarının da yeterince karşılanması gerekir. Bu nedenle psikolojik ihtiyaçlar insan yaşamında çok önemli bir yere sahiptir ve çeşitli alanlara olan yönelimlerini etkilemektedir (Nigar, 2014: 15).

İnsanların yaşadıkları hayatın kalitesini değerlendirerek iyi bir yaşamları olup olmadığına karar vermeleri "iyi yaşam" veya "öznel iyi olma" olarak tanımlanmaktadır ve bu durum mutluluk olarak ifadelendirilmektedir. İnsanların yaşamları boyunca temel psikolojik ihtiyaçlarını doyurabilmeleri iyi olma düzeyleri için önemli bir faktördür. Öznel iyi olma halinde insanların olumlu duyguları ve yaşam doyumu artarken olumsuz duyguları ise azalmaktadır. Temel psikolojik ihtiyaçlarını karşılayan bireylerin iyi olma düzeylerinin de yüksek olduğunu ileri süren araştırmalar yapılmıştır. Yapılan bu araştırmalarda öznel iyi olmanın göstergesi olarak yaşam doyumu, kaygı ve özsaygı olmak üzere üç değişken kullanılmıştır. Örneğin öz-belirleme kuramına göre bu üç doğal ihtiyacın karşılanması iyi olma için gerekli olan koşuldur. Herhangi bir kültürdeki bireyin, içinde bulunduğu ortamda ihtiyaçlarını karşılama derecesi onun iyi olma düzeyini de belirleyen en temel unsurdur (Cihangir-Çankaya, 2009: 28).

Temel psikolojik ihtiyaçların anlaşılması için birçok kuramcı çeşitli araştırmalar yapmışlardır. Bu araştırmaların ilki McDougall tarafından yapılmıştır. Daha sonraki yıllarda ise Freud İçgüdüler Kuramı'nda, Maslow İhtiyaçlar Hiyerarşisi Kuramı'nda insanların ihtiyaçları hakkındaki görüşlerini belirtmişlerdir. Yine bu konuda Alderfer Erg Kuramı, Eric Fromm İhtiyaçlar Kuramı, Murray İhtiyaçlar 
Kuramı, Deci ve Ryan Temel Psikolojik İhtiyaçlar Kuramı ve Glasser Gerçeklik Terapisi ve Seçim-Kontrol Kuramı'nı geliştirmiştir (Nigar, 2014: 23).

\section{İhtiyaç Kuramları}

İhtiyaçların insan davranışları üzerindeki etkisini açıklayan ilk kuramlardan biri olan Psikanalitik Kuram'a göre, organizma eksikliğini hissettiği nesneyi arayarak onu rahatsız eden uyaranı yok etmek ister ve ihtiyaç duyduğu şeyi bulduğunda bu uyaranı yok ederek bozulan dengeyi yeniden sağlar (Çelikkaleli, Gökçakan ve Çapri, 2005: 247). İnsanlar ihtiyaçlarını doyurmak için davranışta bulunurlar. Davranışların ihtiyaçlara dayandırılıp bunların listelenmesi Murray'in "kişilik analizine" dayanmaktadır. Murray'in ihtiyaçları sıralama girişiminden sonra Maslow da ihtiyaçları sınıflama yoluna gitmiştir ve bu şekilde oluşmaya başlayan ihtiyaç kuramlarının temelinde yatan görüşe göre insanların muhtemelen biyolojik kökenli olan psikolojik ihtiyaçları vardır ve bu ihtiyaçlar insan davranışlarının arkasındaki itici gücü oluşturmaktadır (Bozanoğlu, 2012: 5-6).

Murray'ın ihtiyaç-baskı modeliyle açıkladı̆̆ı kuramına göre; bireylerin ihtiyaçları ile çevrenin özellikleri arasındaki uyum önemlidir ve bu uyumun seviyesi bireylerde ihtiyaçlara ilişkin doyum ya da ihtiyaçlara ilişkin yoksunluğa neden olur (Irak, 2012: 13). Murray kuramında 15 farklı psikolojik ihtiyaç tanımlamıştır. Bunlar; Başarma, Başatlık, Değişiklik, Duyguları Anlama, Düzen, Gösteriş, İlgi Görme, Karşı Cinsle İlişki, Kendini Suçlama, Özerklik, Saldırganlık, Sebat, Şefkat Gösterme, Uyarlık ve Yakınlık ihtiyaçlarıdır (Akt: Çelikkaleli vd., 2005: 248).

Maslow'un İhtiyaçlar Hiyerarşisi Kuramı'na göre insanın her davranışı onun sahip olduğu belirli ihtiyaçlarını gidermeye yöneliktir ve ihtiyaçlar davranışı belirleyen önemli faktördür. Kişi daha alt sırada olan ihtiyaçlarını karşılamadan bir üst sıradaki ihtiyaçlarını karşılamaya yönelemez. Maslow'a göre bütün insan ihtiyaçları kendini gerçekleştirme, saygınlık, sosyal, güvenlik ve fizyolojik ihtiyaçlar olmak üzere beş kademe içinde incelenebilir (Burger, 2006: 431). İhtiyaçları önem s1rasına koyan ve doyurulan ihtiyaçların motive edici etkisini yitireceğini belirten Maslow, ifade ettiği bu beş ihtiyacı üstteki ve daha alttaki ihtiyaçlar olarak da iki bölüme ayırmıştır. Bu iki sıralama arasındaki temel fark; yüksek düzeydeki ihtiyaçların içsel olarak, düşük düzeydeki ihtiyaçların ise dışsal olarak tatmin edilmesinden kaynaklanmaktadır (Toker, 2007: 95).

Başarma İhtiyacı Kuramı olarak adlandırılan Mc Clelland tarafından geliştirilen başarı ihtiyaç teorisine göre başarılı olmak isteyen birey başarısızlığa uğramamak için üst derecede ve güç sayılabilecek amaçlar yerine orta ağırlıklı amaçları benimser. Birey başarısızlığa uğramamak için çok aşırı derecede risk üstlenmez. Bununla 
birlikte çok düşük riskli işler de üstlenmez. Birey başarısının çevresindeki kişilerden ve toplumdan yansımasını isteyecektir. Bu övgü niteliğinde olduğu gibi para da olabilir (Duran, Büber ve Gümüştekin, 2013: 41). Bu teoriye göre kişi başarma, güç ve ilişki ihtiyacı olarak tanımlanan üç grup ihtiyacın etkisi altında davranış gösterir ve bu güdülerin her biri kişide farklı bir tatmin duygusu doğurur (Akt: Erdem, 1997: 75).

Bir başka ihtiyaç kuramı kuramcısı olan Erich Fromm'a göre, insanlar içinde yaşadıkları ve bulundukları sistemlerin ihtiyaçlarına göre davranırlar. Bu nedenle içinde yaşanan kültürün sosyoekonomik durumları o kültürde yaşayan insanların ihtiyaçlarının şekillenmesini de önemli ölçüde etkilemektedir (Çelikkaleli vd., 2005: 248).

Glasser'in Gerçeklik Terapisi insanların çoğunun altta yatan benzer problemlere sahip olduğunu savunmaktadır. Bu problem ise genellikle yaşamlarındaki önemli insanlardan en az biriyle doyurucu ve başarılı bir ilişki kuramamaları veya diğer insanlara yaklaşıp onlara bağlanamamalarıdır (Corey, 2008: 346). Seçim kuramını oluşturan Glasser sonraki süreçte kuramını geliştirerek insanın nasıl ve neden davrandığını ele alan kontrol kuramını oluşturmuştur (Kaner, 1993: 569).

Seçim kuramına göre diğer insanlar bizi mutlu da edemez mutsuz da. Diğer insanlardan alabileceğimiz ya da onlara verebileceğimiz şey sadece bilgidir. Bununla birlikte seçimlerimiz olmasaydı bilgi de bir işe yaramazdı. İşte seçim kuramı bu seçimlerimizin nasıl ve neden yapıldığını açıklamaktadır. Bu nedenle seçim kuramı iç kontrol psikolojisi olarak nitelendirilebilir (Hillis, 2008, Akt: Tanrıkulu, 2013: 31). Seçim teorisine göre; birey, sadece kendi davranışlarını kontrol edebilecek bir yeterliliğe sahiptir (Glasser, 1997; Özmen, 2006). Başka insanların davranışları ve istekleri üzerinde kontrolümüz yoktur. Biz sadece kendi davranışlarımızı kontrol edebiliriz (Glasser, 1985, Akt: Tanrıkulu, 2013: 31). Glasser'e göre insanın genetik yapısından kaynaklanan beş temel güdü vardır (Glasser, 1985 Akt: Tanrıkulu, 2013: 32). Bunlar; 1. Hayatta kalma ve üreme, 2. Ait olma (sevme-sevilme ve değerli olma), 3. Güç elde etme, 4. Özgür olma ve 5. Eğlenme. Psikolojik ihtiyaçlar engellendiğinde sergilenen davranışlar, sağlıklı ve dengeli olmayacağından bireyin yaşamda doyum sağlamasını engeller.

\section{Yöntem}

Araştırma; 400 anne ve 400 baba olmak üzere toplam 800 katılımcı ile gerçekleştirilmiştir. Katılımcıların \% 8,1'i 35-40 yaş arası, \% 25,6'sı 41-45 yaş arası, \% 38,1'i 46-50 yaş arası, \% 18,8'i 51-55 yaş arası ve \% 9,4'ü 56 ve üstü yaşa sahiptir. Kat1- 
lımcılardan; \% 68,1'i 20-25 yıl, \% 15'i 26-30 yıl, \% 11,3'ü 31-35 yıl ve \% 5,6'sı 36 yıl ve üzeri evlilik süresine sahiptir. Katılımcılardan \% 6'sı tek çocuk, \% 25,6'sı ilk çocuk, \% 58,8'i ortanca çocuk ve \% 15'i son çocuk olarak dünyaya gelmişlerdir. Katılımcıların \% 75,1'i görücü usulü ve \% 24,1'i ise flört usulü ile evlenmişlerdir.

\section{Verilerin Toplanması ve Veri Toplama Araçları}

Araştırmada veriler, "Yapılandırılmış Görüşme Formu" ile toplanmıştır. Verilerin toplanması sürecinde aşağıdaki süreç takip edilmiştir. Sakarya Üniversitesi Eğitim Fakültesi'nin farklı anabilim dallarında öğrenim gören ve araştırmaya gönüllü olarak katılmayı kabul eden öğrencilere araştırmanın amacı ve "Temel Psikolojik İhtiyaçları Belirleme Formunu" nasıl kullanacakları öğretilmiştir. Her bir öğrenci bu eğitimden sonra hem annesini hem de babasını telefon ile arayarak ya da yüz yüze görüşme imkânı olanlar anne babası ile ayrı ayrı görüşerek formu doldurmuş ve araştırmacılara teslim etmiştir. Formda yer alan temel psikolojik ihtiyaçları formda yazıldığı sıra ile değil rastgele sormaları sağlanmıştır. Form iki bölümden oluşmaktadır. Birinci bölümde, anne ve babaya ait demografik bilgiler; yaş, eğitim düzeyi, evlilik süresi, evlenme şekli (görücü; flört vb), mesleği, dünyaya geliş sırası, çocuk sayısı gibi demografik bilgileri elde etmeye yönelik sorular yer almaktadır. İkinci bölümde ise, Temel Psikolojik İhtiyaçları önem sırasına göre en önemlisine bir (1) vererek sıralama yapmalarını belirleyecek bölüm yer almaktadır. Bu bă̆lamda 400 anne ve 400 baba olmak üzere araştırma toplam 800 kişi ile gerçekleştirilmiştir. Veriler tanımlayıcı istatistiksel yöntemlerle analiz edilmiştir.

\section{Verilerin Analizi}

Veri analizi, SPSS istatistik paket programı yardımı ile gerçekleştirilmiştir. Analizler, katılımcıların ailenin karşıladığını düşündükleri temel psikolojik ihtiyaçlardan birinci sırada gördüklerine yönelik olarak yapılmıştır. İkinci, üçüncü, dördüncü ve beşinci sıra gördükleri ve bu bağlamda verdikleri cevaplara ilişkin analizler yapılmamıştır. Çünkü bu çalışmanın temel amacı ailenin karşıladığı temel psikolojik ihtiyacın hangisi olduğunu belirlemektir. Veriler, frekans ve yüzdelikler olarak analiz edilmiş ve frekanslara dayalı sonuçlar grafiklerle gösterilmiştir.

\section{Bulgular}

\section{Ebeveynlere göre ailenin birinci sırada karşıladığı temel psikolojik ihtiyacın hangisi olduğuna ilişkin bulgular.}


Şekil 1. Ebeveynlere göre ailenin birinci sırada karşıladığı temel psikolojik ihtiyaç.

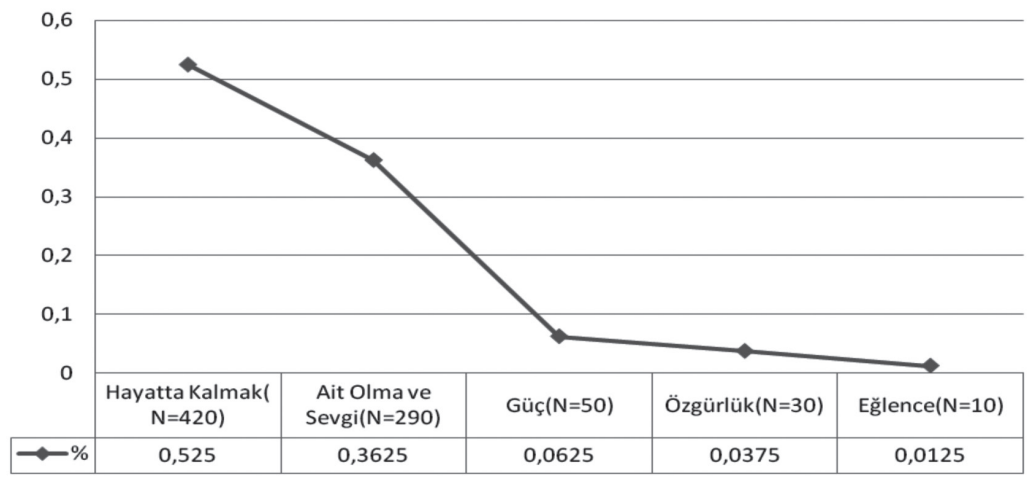

Ebeveynlere göre ailenin birinci sırada karşıladığı temel psikolojik ihtiyaca ilişkin sonuçlar şekil 1'de verilmiştir. Şekil 1'e göre hayatta kalma katılımcıların büyük kısmına (\% 52,5) göre ailenin karşıladığı temel psikolojik ihtiyaçlardan ilk sırada yer alan ihtiyaçtır. Hayatta kalma temel psikolojik ihtiyacını sırasıyla ait olma $(\% 36,25)$, güç $(\%$ 6,25), özgürlük $(\% 3,75)$ ve eğlence $(\% 1,25)$ temel psikolojik ihtiyacı izlemektedir.

\section{Cinsiyet değişkenine göre ailenin karşıladığı temel psikolojik ihti- yaçlara ilişkin bulgular.}

Tablo 1. Cinsiyet değişkenine göre ailenin karşıladığı temel psikolojik ihtiyaçların siralanmasi.

\begin{tabular}{|c|c|c|c|c|c|c|c|c|c|c|}
\hline \multirow[b]{3}{*}{ Cinsiyet } & \multicolumn{10}{|c|}{ TEMEL PSİKOLOJIK İHTIYAÇLAR } \\
\hline & \multicolumn{2}{|c|}{$\begin{array}{l}\text { Hayatta } \\
\text { Kalmak }\end{array}$} & \multicolumn{2}{|c|}{$\begin{array}{l}\text { Ait Olma ve } \\
\text { Sevgi }\end{array}$} & \multicolumn{2}{|l|}{ Güç } & \multicolumn{2}{|c|}{ Özgürlük } & \multicolumn{2}{|c|}{ Eğlence } \\
\hline & $\mathrm{N}$ & $\%$ & $\mathrm{~N}$ & $\%$ & $\mathrm{~N}$ & $\%$ & $\mathrm{~N}$ & $\%$ & $\mathrm{~N}$ & $\%$ \\
\hline Kadın & 201 & 50 & 174 & 44 & 15 & 4 & 5 & 1 & 5 & 1 \\
\hline Erkek & 219 & 55 & 116 & 29 & 35 & 9 & 25 & 6 & 5 & 1 \\
\hline
\end{tabular}


Şekil 2. Cinsiyet değişkenine göre ailenin karşıladığı temel psikolojik ihtiyaçlar.

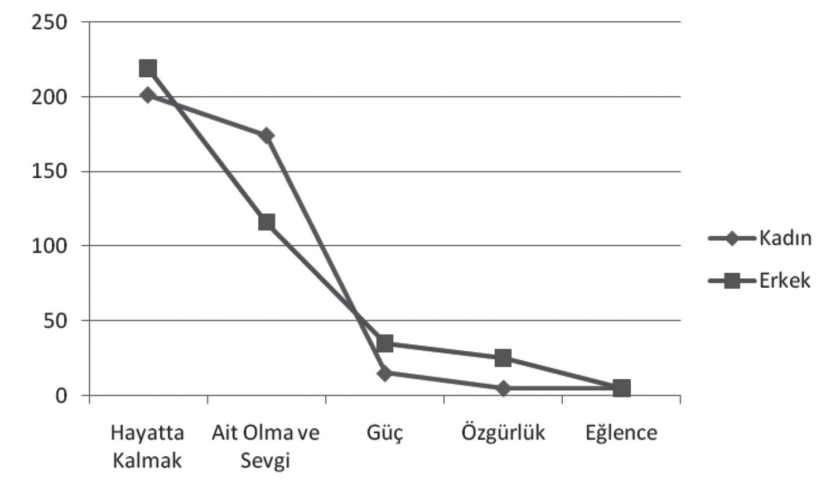

Cinsiyet değişkenine göre ailenin karşıladığı temel psikolojik ihtiyaçların sıralanması tablo 1'de verilmiştir. Tablo 1'e göre ailenin karşıladığı ilk sıradaki temel psikolojik ihtiyaç kadın katılımcılar için hayatta kalma (\% 50), ait olma ve sevgi (\% 44), güç (\% 4), özgürlük (\% 1) ve eğlence (\% 1) şeklinde sıralanmaktadır. Bu sıralama erkek katılımcılar için hayatta kalma (\% 55), ait olma ve sevgi (\% 29), güç (\% 9), özgürlük (\% 6) ve eğlence (\% 1) şeklindedir. Cinsiyet değişkene göre ailenin karşıladığı temel psikolojik ihtiyaçlar grafiği şekil 2'de verilmiştir.

\section{Yaş değişkenine göre ailenin karşıladığı temel psikolojik ihtiyaçlara ilişkin bulgular.}

Tablo 2. Yaş değişkenine göre ailenin karşıladığı temel psikolojik ihtiyaçların sıralanması.

\begin{tabular}{|c|c|c|c|c|c|c|c|c|c|c|c|}
\hline \multirow[b]{3}{*}{ Yaş } & \multirow[b]{3}{*}{$\mathrm{N}$} & \multicolumn{10}{|c|}{ Temel Psikolojik ihtiyaçlar } \\
\hline & & \multicolumn{2}{|c|}{ Hayatta Kalmak } & \multicolumn{2}{|c|}{ Ait Olma ve Sevgi } & \multicolumn{2}{|c|}{ Güç } & \multicolumn{2}{|c|}{ Özgürlük } & \multicolumn{2}{|c|}{ Eğlence } \\
\hline & & $\mathrm{N}$ & $\%$ & $\mathrm{~N}$ & $\%$ & $\mathrm{~N}$ & $\%$ & $\mathrm{~N}$ & $\%$ & $\mathrm{~N}$ & $\%$ \\
\hline 35-40 Arası & 65 & 50 & 76,92 & 15 & 23,1 & 0 & 0 & 0 & 0 & 0 & 0 \\
\hline 41-45-Arası & 205 & 110 & 53,65 & 90 & 43,9 & 5 & 2,43 & 0 & 0 & 0 & 0 \\
\hline 46-50 Aras1 & 305 & 150 & 49,18 & 115 & 37,7 & 25 & 8,19 & 15 & 4,91 & 5 & 1,63 \\
\hline 51-55 Arası & 150 & 75 & 50.00 & 35 & 23,3 & 25 & 16,66 & 20 & 13,33 & 5 & 3,33 \\
\hline 56 ve Üst & 75 & 35 & 46,66 & 35 & 46,7 & 5 & 6,66 & 0 & 0 & 0 & 0 \\
\hline
\end{tabular}




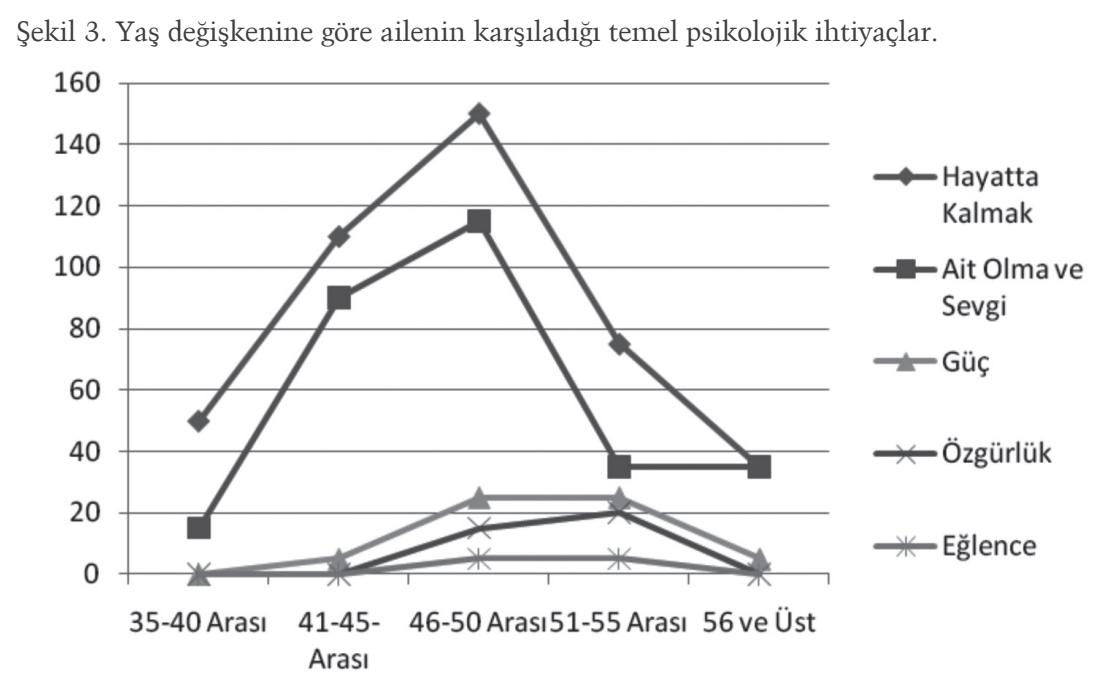

Yaş değişkenine göre ailenin karşıladığı temel psikolojik ihtiyaçların sıralanması tablo 2'de verilmiştir. Tablo 2'ye göre 35-40 yaş arası katılımcıların ilk sırada belirttikleri temel psikolojik ihtiyaçlar \% 76,92 oranında hayatta kalma ve \% 23,1 oranında ait olma ve sevgidir. 41-45 yaş arasındaki katılımcılar için hayatta kalma \% 53,65 oranında, ait olma ve sevgi \% 43,9 oranında, güç \% 2,43 oranında ilk sırada yer alan temel psikolojik ihtiyaç olarak belirtilmiştir. 46-50 yaş arasındaki katılımcılar için hayatta kalma \% 49,18 oranında, ait olma ve sevgi \% 37,7 oranında, güç, \% 8,19 oranında, özgürlük \% 4,91 oranında, eğlence ise \% 1,63 oranında ilk sırada yer alan temel psikolojik ihtiyaç olarak belirtilmiştir. 51-55 yaş arasındaki katılımcılar için hayatta kalma \% 50 oranında, ait olma ve sevgi \% 23,3 oranında, güç \% 16,66 oranında, özgürlük \% 13,33 oranında, eğlence ise \% 3,33 oranında ilk sırada yer alan temel psikolojik ihtiyaç olarak belirtilmiştir. 56 yaş ve üstündeki katılımcılar için hayatta kalma \% 46,66 oranında, ait olma ve sevgi \% 46,7 oranında, güç \% 6,66 oranında ilk sırada yer alan temel psikolojik ihtiyaç olarak belirtilmiştir. 35-40 yaş, 41-45 yaş ve 55 yaş ve üstündeki katılımcı grupları için özgürlük ve eğlence ilk sırada yer alan temel psikolojik ihtiyaçlar arasında belirtilmemiştir. Ayrıca 35-40 yaş arasındaki katılımcılar güç temel psikolojik ihtiyacını da ilk sırada belirtmemiştir. Yaş değişkene göre ailenin karşıladığı temel psikolojik ihtiyaçlar grafiği şekil 3'de verilmiştir. 


\section{Evlilik süresi değişkenine göre ailenin karşıladığı temel psikolojik ihtiyaçlara ilişkin bulgular.}

Tablo 3. Evlilik süresi değişkenine göre ailenin karşıladığı temel psikolojik ihtiyaçların siralanmasi.

\begin{tabular}{|c|c|c|c|c|c|c|c|c|c|c|c|}
\hline \multirow[b]{3}{*}{ Evlilik Süresi } & \multirow[b]{3}{*}{$\mathrm{N}$} & \multicolumn{10}{|c|}{ TEMEL PSIKOLOJIK İHTIYAÇLAR } \\
\hline & & \multicolumn{2}{|c|}{ Hayatta Kalmak } & \multicolumn{2}{|c|}{ Ait Olma ve Sevgi } & \multicolumn{2}{|c|}{ Güç } & \multicolumn{2}{|c|}{ Özgürlük } & \multicolumn{2}{|c|}{ Eğlence } \\
\hline & & $\mathrm{N}$ & $\%$ & $\mathrm{~N}$ & $\%$ & $\mathrm{~N}$ & $\%$ & $\mathrm{~N}$ & $\%$ & $\mathrm{~N}$ & $\%$ \\
\hline $20-25$ yil & 545 & 310 & 56,88 & 185 & 33,94 & 30 & 5,51 & 15 & 2,75 & 5 & 0,91 \\
\hline $26-30$ y1l & 120 & 50 & 41,66 & 50 & 41,66 & 10 & 8,33 & 10 & 8,33 & 0 & 0 \\
\hline $31-35$ y1l & 90 & 45 & 50 & 30 & 33,33 & 10 & 11,11 & 10 & 11,11 & 5 & 5,55 \\
\hline $36+$ & 45 & 0 & 0 & 25 & 55,55 & 10 & 22,22 & 0 & 0 & 0 & 0 \\
\hline
\end{tabular}

Şekil 4. Evlilik süresi değişkenine göre ailenin karşıladığı temel psikolojik ihtiyaçlar.

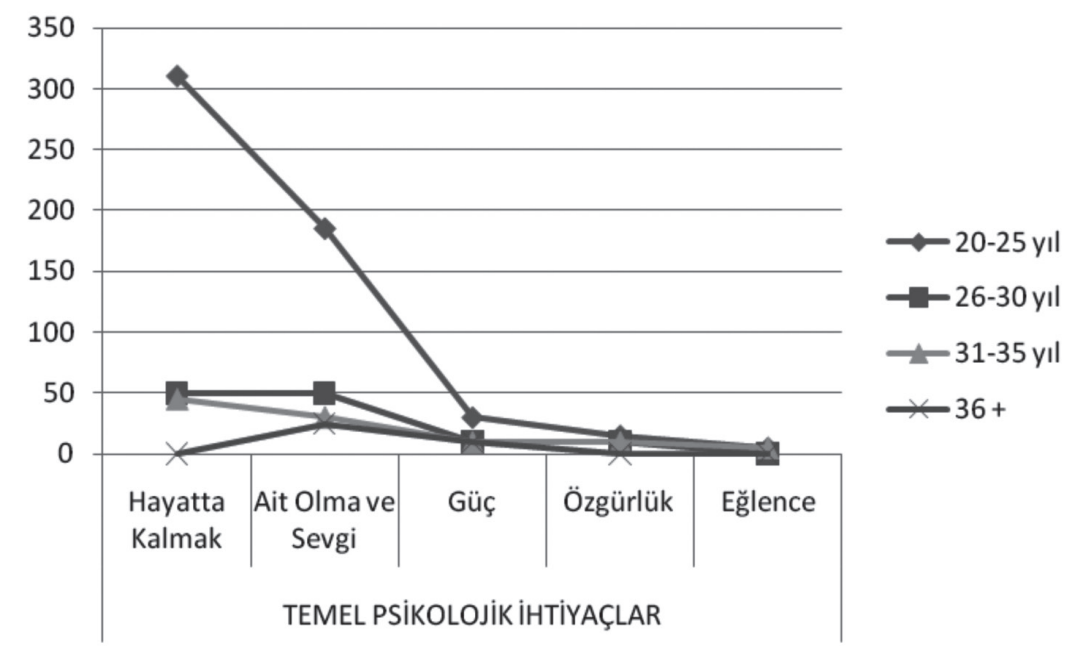


Evlilik süresi değişkenine göre ailenin karşıladığı temel psikolojik ihtiyaçların s1ralaması tablo 3'de verilmiştir. Tablo 3'e göre 20-25 yıl arası evlilik süresine sahip katılımcıların \% 56,88'i hayatta kalma temel psikolojik ihtiyacını, \% 33,94'ü ait olma ve sevgi temel psikolojik ihtiyacını, \% 5,51'i güç temel psikolojik ihtiyacını, \% 2,75'i özgürlük temel psikolojik ihtiyacını ve \% 0,91'i eğlence temel psikolojik ihtiyacını ilk sırada belirtmiştir. 26-30 yıl arası evlilik süresine sahip katılımcılarin \% 41,66's1 hayatta kalma temel psikolojik ihtiyacinı, \% 41,66's1 ait olma ve sevgi temel psikolojik ihtiyacını, \% 8,33'ü güç temel psikolojik ihtiyacını, \% 8,33'ü özgürlük temel psikolojik ihtiyacını ilk sırada belirtmiştir. 31-35 yıl arası evlilik süresine sahip katılımcıların \% 50'si hayatta kalma temel psikolojik ihtiyacını, \% 33,33'ü ait olma ve sevgi temel psikolojik ihtiyacını, \% 11,11'i güç temel psikolojik ihtiyacını, \% 11,11'i özgürlük temel psikolojik ihtiyacını ve \% 5,55'i eğlence temel psikolojik ihtiyacını ilk sırada belirtmiştir. 36 yıl ve üzeri evlilik süresine sahip katılımcıların \% 55,55'i ait olma ve sevgi temel psikolojik ihtiyacını, \% 22,22'si güç temel psikolojik ihtiyacını ilk sırada belirtmiştir. 26-30 yıl arası evlilik süresine sahip katılımcılar için eğlence temel psikolojik ihtiyacı ilk sırada yer almazken, 36 yıl ve üzeri evlilik süresine sahip katılımcılar için hayatta kalma, özgürlük ve eğlence temel psikolojik ihtiyacı ilk sırada yer almamıştır. Evlilik süresi değişkene göre ailenin karşıladığı temel psikolojik ihtiyaçlar grafiği şekil 4'de verilmiştir.

\section{Evlenme şekli değişkenine göre ailenin karşıladığı temel psikolojik ihtiyaçlara ilişkin bulgular.}

Tablo 4. Evlenme şekli değişkenine göre ailenin karşıladığı temel psikolojik ihtiyaçların siralanmasi.

\begin{tabular}{|c|c|c|c|c|c|c|c|c|c|c|c|}
\hline \multirow[b]{3}{*}{ Evlilik Şekli } & \multirow[b]{3}{*}{$\mathrm{N}$} & \multicolumn{10}{|c|}{ TEMEL PSİKOLOJIK İHTİYAÇLAR } \\
\hline & & \multicolumn{2}{|c|}{ Hayatta Kalmak } & \multicolumn{2}{|c|}{ Ait Olma ve Sevgi } & \multicolumn{2}{|c|}{ Güç } & \multicolumn{2}{|c|}{ Özgürlük } & \multicolumn{2}{|c|}{ Eğlence } \\
\hline & & $\mathrm{N}$ & $\%$ & $\mathrm{~N}$ & $\%$ & $\mathrm{~N}$ & $\%$ & $\mathrm{~N}$ & $\%$ & $\mathrm{~N}$ & $\%$ \\
\hline Görücü & 601 & 316 & 52,57 & 225 & 37,43 & 35 & 5,82 & 30 & 4,99 & 10 & 1,66 \\
\hline Flört & 199 & 104 & 52,26 & 65 & 32,66 & 25 & 12,56 & 5 & 2,51 & 10 & 5,02 \\
\hline
\end{tabular}


Şekil 5. Evlenme şekli değişkenine göre ailenin karşıladığı temel psikolojik ihtiyaçlar.

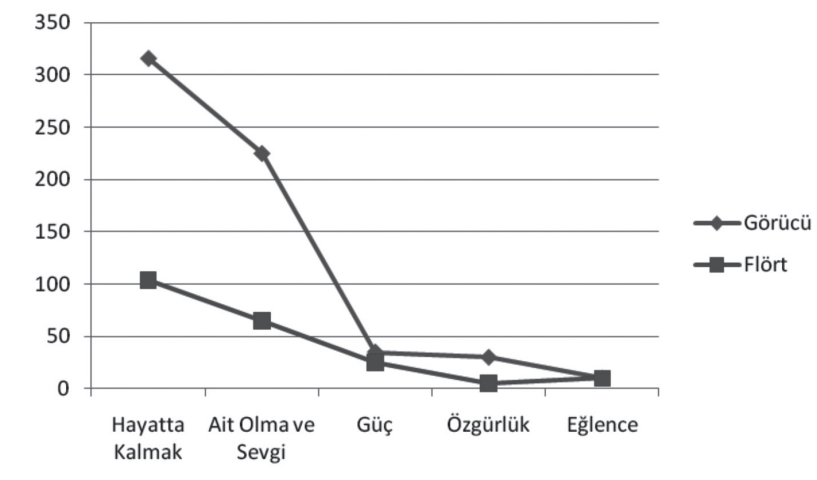

Evlenme şekli değişkenine göre ailenin karşıladığı temel psikolojik ihtiyaçların sıralanması tablo 4'de verilmiştir. Tablo 4'e göre görücü usulüyle evlenen katılımcıların temel psikolojik ihtiyaçlar sıralamasında hayatta kalma \% 52,57 oranında, ait olma ve sevgi \% 37,43 oranında, güç \% 5,82 oranında, özgürlük \% 5,99 oranında ve eğlence \% 1,66 oranında ilk sırada belirtilmiştir. Flört sonucu evlenen katılımcıların temel psikolojik ihtiyaçlar sıralamasında hayatta kalma \% 52,26 oranında, ait olma ve sevgi \% 32,66 oranında, güç \% 12,56 oranında, özgürlük \% 2,51 oranında ve eğlence \% 5,02 oranında ilk sırada belirtilmiştir. Evlenme şekli değişkenine göre ailenin karşıladığı temel psikolojik ihtiyaçlar grafiği şekil 5'de verilmiştir.

\section{Dünyaya geliş sırası değişkenine göre ailenin karşıladığı temel psi- kolojik ihtiyaçlara ilişkin bulgular.}

Tablo 5. Dünyaya geliş sırası değişkenine göre ailenin karşıladığı temel psikolojik ihtiyaçların sıralanması.

\begin{tabular}{|c|c|c|c|c|c|c|c|c|c|c|c|}
\hline \multirow[b]{3}{*}{ Doğum Sırası } & \multirow[b]{3}{*}{$\mathrm{N}$} & \multicolumn{10}{|c|}{ TEMEL PSİKOLOJIK İHTIYYAÇLAR } \\
\hline & & \multicolumn{2}{|c|}{ Hayatta Kalmak } & \multicolumn{2}{|c|}{ Ait Olma ve Sevgi } & \multicolumn{2}{|c|}{ Güç } & \multicolumn{2}{|c|}{ Özgürlük } & \multicolumn{2}{|c|}{ Eğlence } \\
\hline & & $\mathrm{N}$ & $\%$ & $\mathrm{~N}$ & $\%$ & $\mathrm{~N}$ & $\%$ & $\mathrm{~N}$ & $\%$ & $\mathrm{~N}$ & $\%$ \\
\hline Tek Çocuk & 5 & 5 & 100 & 0 & 0 & 0 & 0 & 0 & 0 & 0 & 0 \\
\hline İlk Çocuk & 205 & 95 & 46,34 & 85 & 41,46 & 15 & 7,31 & 15 & 7,31 & 0 & 0 \\
\hline Ortanca Çocuk & 470 & 260 & 55,31 & 165 & 35,1 & 35 & 7,44 & 35 & 7,44 & 10 & 2,1 \\
\hline Son Çocuk & 102 & 60 & 50 & 40 & 33,33 & 10 & 8,33 & 10 & 8,33 & 0 & 0 \\
\hline
\end{tabular}


Şekil 6. Dünyaya geliş sırası değişkenine göre ailenin karşıladığı temel psikolojik ihtiyaçlar.

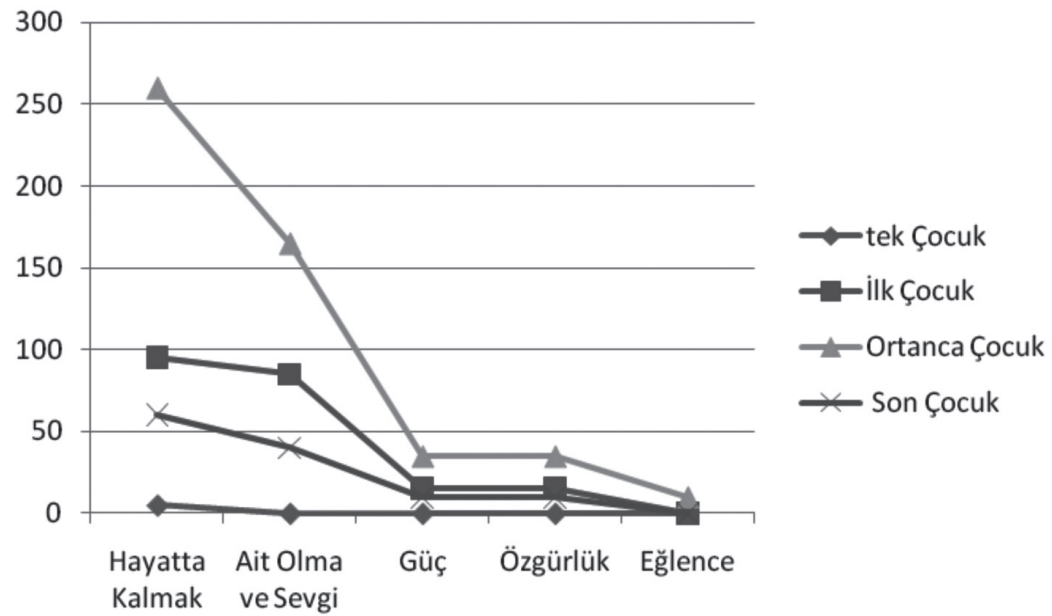

Dünyaya geliş sırası değişkenine göre ailenin karşıladığı temel psikolojik ihtiyaçların sıralanması tablo $5^{\prime}$ te verilmiştir. Tablo 5'e göre ailelerinin tek çocuğu olan katılımcılar için \% 100 oranında hayatta kalma temel ihtiyacı ilk sırada yer almaktadır. İlk çocuk olan katılımcılar için hayatta kalma \% 46,34 oranında, ait olma ve sevgi \% 41,46 oranında, güç \% 7,31 oranında, özgürlük \% 7,31 oranında ilk sırada yer alan temel psikolojik ihtiyaçtır. Ortanca çocuk olan katılımcılar için hayatta kalma \% 55,31 oranında, ait olma ve sevgi \% 35,1 oranında, güç \% 7,44 oranında, özgürlük \% 7,44 oranında, eğlence \% 2,1 oranında ilk sırada yer alan temel psikolojik ihtiyaçtır. Son çocuk olan katılımcılar için hayatta kalma \% 50 oranında, ait olma ve sevgi \% 33,33 oranında, güç \% 8,33 oranında, özgürlük \% 8,33 oranında ilk sırada yer alan temel psikolojik ihtiyaçtır. Eğlence sadece ortanca çocuk olan katılımcılar tarafından temel psikolojik ihtiyaçlar sıralamasında ilk sırada belirtilmiştir. Aynı zamanda tek çocuk olan katılımcılar için ait olma ve sevgi, güç ve özgürlük de ilk sırada yer alan temel psikolojik ihtiyaçlar arasında belirtilmemiştir. Dünyaya geliş sırası değişkenine göre ailenin karşıladığı temel psikolojik ihtiyaçlar grafiği şekil 6'da verilmiştir. 


\title{
Sonuç
}

\begin{abstract}
A ilenin karşıladığı temel psikolojik ihtiyaçlar sırasıyla, hayatta kalmak, ait olma ve sevgi, güç, özgürlük ve eğlence şeklinde sıralanmıştır. Ailenin en çok hayatta kalma ihtiyacını karşılaması, Maslow'un temel ihtiyaçlar hiyerarşisi referans alındığında, temel ihtiyaçların birinci basamakta olması ile örtüşmektedir. Burada tartışılması gereken durum evlilik süreleri ve katılımcıların yaşları dikkate alındığında ailenin halen birinci sırada hayatta kalma ihtiyacını karşılıyor olarak belirtilmiş olmasıdır. Aile ve bu aileyi oluşturan bireyler, kendilerini aile ile ilişkilendirdiklerinde daha güvenli, değerli, işe yarar, önemli ve onaylanmış olarak hissetmelidir.
\end{abstract}

Psikolojik ihtiyaçların cinsiyete göre farklılık gösterip göstermediğini test eden araştırmalar literatürde mevcuttur. Gündoğdu ve Yavuzer (2012: 122) cinsiyetin öğrencilerin temel psikolojik ihtiyaçlar ve öznel iyi oluş puanları üzerindeki temel etkileri anlamlı bulmuştur. Kuru ve Baştuğ (2006: 124) tarafından 120 futbolcu ile yapılan bir çalışmada, bayan ve erkek futbolcuların psikolojik ihtiyaçları cinsiyet değişkenine göre incelenmiş, bayan ve erkek futbolcularda başatlık, şefkat gösterme, değişiklik, karşı cinsle ilişki ve saldırganlık özellikleri açısından anlamlı farklılıklar bulunmuştur. Çalık, Özbay, Özer, Kurt ve Kandemir (2009: 567) tarafından yapılan araştırmada psikolojik ihtiyaçların cinsiyetlere, okullara, anne ve babanın eğitim düzeyine göre farklılaştığı bulunmuştur. Nigar (2014) ise araştırmasında cinsiyet değişkeni ile psikolojik ihtiyaçlar arasında anlamlı bir farklılık bulunmamıştır. Mevcut araştırmada cinsiyet değişkenine göre ve her bir psikolojik ihtiyaç kendi içinde karşılaştırıldığında (bkz. şekil 2) erkek ebeveynler kadınlara oranla ailenin daha çok hayatta kalma temel psikolojik ihtiyacını karşıladığını, kadın ebeveynler ise erkeklere oranla ailenin daha çok ait olma ve sevgi ihtiyacını karşıladığını düşünmektedir. Cinsiyete göre değerlendirildiğinde, erkek ebeveynlerin ailenin daha çok hayatta kalma ihtiyacını karşılıyor olarak algılamalarının temel nedeni soyun devamının sağlanması, çocukları için güvenli bir sığınak oluşturması ve bunun sonucunda erkeğin de kendini güvende hissedebildiği düşünül- 
mektedir. Kadın ebeveynlerin ise ailenin karşıladığı temel psikolojik ihtiyacın ait olma ve sevgi olarak tercih etmesinin nedeni, annenin kendisini bir aileye ait hissettiğinde kendini güçlü ve varlığının onaylanmış olduğunu anlamasıdır. Bu onun gerçeklerle yüzleşmesini sağlayan en temel unsurdur. Stres karşısında kadınların daha dik duruşları belki de bu özellikten ileri gelebilmektedir. Aile, kadın ebeveyne erkek ebeveynden daha fazla ait olma duygusu yaşatmaktadır. Cihangir-Çankaya (2009: 27) tarafından yürütülen araştırmada bireylerin aile ve arkadaş çevresinden aldıkları özerklik desteğinin, onların temel psikolojik ihtiyaçlarının doyumunu etkilediği, temel psikolojik ihtiyaçların doyumunun da öznel iyi olmayı olumlu yönde etkilediği bulunmuştur. Hamurcu ve Sargın (2011: 179) psikolojik ihtiyaçların ilişki alt boyutu ile boyun eğme davranışı arasında da negatif yönde ilişki tespit edilmiştir. Boyun eğme davranışının en güçlü yordayıcısı özerklik, diğeri ise ilişki ihtiyacı olarak belirlenmiştir.

Yaş ve Evlilik süresine göre ailenin hayatta kalma temel psikolojik ihtiyacını karşıladığına ilişkin görüşlerinde azalma, ait olma ve sevgi ihtiyacını karşıladığına ilişkin görüşlerde artma olmaktadır. Yaş ilerledikçe ailenin üyeleri özellikle anne ve babaların birbirilerini çok daha iyi tanımaları, birbirilerine karşı olan tutumları ve bu tutumlarındaki tutarlılık aile ortamını kendileri ve diğer aile üyeleri için güvenli, huzurlu, öngörülebilir, destekleyici ve onaylayıcı bir ortama dönüştürerek aileyi her biri için sığınak haline getirebilmektedir. Artık aile, sorumluluk duygusunun, anlayışın ve iş birliğinin hüküm sürdüğü bir yapıya dönüşmüştür. Ancak böyle bir ortamda ait olma ve sevgi ihtiyacı karşılanabilir. İlgili literatür bu düşünceyi desteklemektedir. Sevme ve ait olma duygusu en temel gereksinimdir, çünkü diğer gereksinimleri karşılamak için insanlara ihtiyacımız vardır. Ayrıca bu ihtiyaç karşılanması en zor olan ihtiyaçtır, çünkü bu ihtiyacın karşılanması için karşımızdaki kişi ile iş birliğine ihtiyaç vardır (Corey, 2008: 247-248).

Evlenme şekli değişkenine göre ailenin karşıladığı temel psikolojik ihtiyacın hangisi olduğuna ilişkin görüşlerde farklılaşma olmaktadır. Görücü ve flört usulü ile evlenen ebeveynler ailenin daha çok hayatta kalma ihtiyacını karşıladığını belirtmişlerdir. Flört usulü ile evlenen ebeveynler görücü usulü ile evlenen ebeveynlere göre ailenin güç ihtiyacını daha fazla karşıladığını belirtmişlerdir. Görücü usulü ile evlenen ebeveynler de flört sonucu evlenen ebeveynlere göre ailenin özgürlük ihtiyacını daha fazla karşıladığını belirtmişlerdir. Bu bulgu bireylerin evlilik öncesi yaşamlarıyla ilgili ipucu niteliğinde görülebilir. Baskıcı ve otoriter aile yapılarından gelen bireylerin evlilik sayesinde özgürlüğü daha fazla yaşayabildikleri şeklinde yorum yapilabilir.

Doğum sırası değişkenine göre ailenin karşıladığı temel psikolojik ihtiyacın hangisi olduğuna ilişkin görüşlerde farklılaşma olmaktadır. Tek çocuk ebeveynler için 
ailenin karşıladığı tek psikolojik ihtiyaç hayatta kalmaktır. Bunun nedeni olarak, bu ebeveynler için ailenin soyun devamı anlamına gelmesi gösterilebilir. İnsanlar, hayatta kalma, soyunu sürdürme ve bunun için ait olmaya ve sevgiye ihtiyacina ihtiyaç duyarlar. İlk, ortanca ve son çocuk için aile hayatta kalma, ait olma ve sevgi ihtiyaçlarını karşılamaktadır.

$\mathrm{Bu}$ araştırma sonucu elde edilen bulgular referans alındığında aşağıdaki öneriler yapılabilir.

1. Aile eğitimlerinin evlilik öncesi ve evlilik sonrası süreçlerinde mutlaka ailenin hangi temel psikolojik ihtiyaçları karşıladığı ya da karşılamadığını belirlemeye ilişkin içerik konulmalıdır.

2. Temel psikolojik ihtiyaçların ne anlama geldiği ve nasıl karşılanabileceğine ilişkin görsel ve yazılı basından yararlanılabilir.

3. Aile üyelerinin her birinin hangi temel psikolojik ihtiyaç anlamında eksiklikler yaşadıklarına ilişkin psikolojik danışma yardımı almaları gerekir.

4. Yerel yönetimlerin bu bağlamda merkezler kurarak üniversitelerin ilgili birimleri ile ortak çalışmalar planlamalarının yararlı olacağı düşünülmektedir. 


\section{Kaynakça}

Bozanoğlu İ. (2012). Akademik Güdülenme Destek Programı. S. Erkan ve A. Kaya (Ed.), Deneysel Olarak Sınanmış Grupla Psikolojik Danışma ve Rehberlik Programları (C. III, s. 1-18). Ankara: Pegem.

Burger, J.M. (2006). Kişilik. İstanbul: Kaknüs.

Cihangir-Çankaya, Z. (2009). Özerklik Desteği, Temel Psikolojik İhtiyaçların Doyumu ve Öznel İyi Olma: Öz-Belirleme Kuramı. Türk Psikolojik Danısma ve Rehberlik Dergisi, 4 (31), 23-31.

Corey, G. (2008). Psikolojik Danısma, Psikoterapi Kuram ve Uygulamalan. Ankara: Mentis.

Çalık, T., Özbay, Y., Özer, A., Kurt, T ve Kandemir, M. (2009). İlköğretim Okulu Ögrencilerinin Zorbalık Statülerinin Okul İklimi, Prososyal Davranışlar, Temel İhtiyaçlar ve Cinsiyet Değişkenlerine göre İncelenmesi. Kuram ve Uygulamada Eğitim Yönetimi Dergisi, 15 (4), 555-576.

Çelikkaleli, Ö., Gökçakan, N ve Çapri, B. (2005). Lise Öğrencilerinin Bazı Psikolojik İhtiyaçlarının Cinsiyet, Okul Türü, Anne ve Baba Eğitim Düzeyine göre İncelenmesi. Uludağ Üniversitesi Eğitim Fakültesi Dergisi, 18 (2), 245-268.

Duran C., Büber, H ve Gümüştekin, E. G. (2013). Girişimcilik Hislerine Eğitimin Katkısı: Kütahya MYO Makine Programı Örneği. Girişimcilik ve Kalkınma Dergisi, 8 (2), 33-56.

Erdem, A.R. (1997). İçerik Kuramları ve Eğitim Yönetimine Katkıları. Pamukkale Üniversitesi Eğitim Fakültesi Dergisi, 3, 68-76.

Glasser, W. (1985). Discipline Has Never Been The Problem and isn't The Problem Now. Theory Into Practice, 24 (4), 241-246. doi:10.1080/00405848509543181.

Glasser, W. (1997). Choice Theory and Student Success. Education Digest, 63 (3), 16-22.

Gündoğdu, R. ve Yavuzer, Y. (2012). Eğitim Fakültesi Öğrencilerinin Öznel İyi Oluş ve Psikolojik İhtiyaçlarının Demografik Değişkenlere göre İncelenmesi. Mehmet Akif Ersoy Üniversitesi Eğitim Fakültesi Dergisi, 12 (23), 115-131. 
Hamurcu, H. ve Sargın, N. (2011). Lise Öğrencilerinin Boyun Eğme Davranışları İle Psikolojik İhtiyaçları Arasındaki İlişkinin İncelenmesi. Sosyal Bilimler Enstitüsü Dergisi, 31 (2), 171-187.

Hillis, P. M. (2008). Choice Theory, Metacognition, and A Life Experience: SelfIntegrity Following Change. International Journal of Reality Therapy, 28 (1), 57-62.

Irak, D. U. (2012). İsyerinde Birey-Çevre Uyumu: Kuramsal Yaklaşımlar ve Örgütsel Psikolojideki Yeri. Türk Psikoloji Yazılan, 15 (30), 12-22.

Kaner, S. (1993). Kontrol Kuramı ve Gerçeklik Terapisi. Ankara Üniversitesi Eğitim Bilimleri Fakültesi Dergisi, 26 (2), 569-585.

Karahan, T. F. ve Sardoğan, M. E. (2004). Psikolojik Danışma ve Psikoterapide Kuramlar (2. Baskı). Samsun: Deniz Kültür.

Kuru, E. ve Baştuğ, G. (2006). Bayan ve Erkek Futbolcuların Psikolojik İhtiyaçlarının Cinsiyet Değisskenine Göre İncelenmesi. Ankara Üniversitesi Beden Ĕ̆itimi ve Spor Bilimleri Dergisi, 4 (3), 117-126.

Nigar, F. (2014). Ortaokul Öğrencileri ile Yatılı Bölge Ortaokul Öğrencilerinin Öznel İyi Oluş ve Temel Psikolojik İhtiyaçlar Düzeyinin Karşılaştırılması. (Yayımlanmamıs yüksek lisans tezi). Gaziosmanpaşa Üniversitesi/Eğitim Bilimleri Enstitüsü, Tokat. file:///C:/Users/cc/Downloads/361658.pdf

Özmen, A. (2006). Seçim Kuramına ve Gerçeklik Terapisine Dayalı Öfkeyle Başa Çıkma Eğitim Programının ve Etkileşim Grubu Uygulamasının Sürekli Öfke Düzeyi Üzerindeki Etkisi. Gazi Üniversitesi Gazi Eğitim Fakültesi Dergisi, 30 (2), 19-36.

Tanrıkul, T. (2013). Siber Zorbalikla İlgili Değişkenlerin Incelenmesi ve Gerçeklik Terapisi Yönelimli Bir Müdahale Programinin Siber Zorbaca Davranişlar Üzerindeki Etkisi (Yayınlanmış doktora tezi). Sakarya Üniversitesi/ Eğitim Bilimleri Enstitüsü, Sakarya.

Toker, B. (2007). Demografik Değişkenlerin İş Tatminine Etkileri: İzmir'deki Beş ve Dört Yıldızlı Otellere Yönelik Bir Uygulama. Doğuş Üniversitesi Dergisi, $8(1), 92-107$. 